\title{
DESCRIPTION OF THE OVA AND OVIPOSITIONAL STRATEGIES OF SIX STERRHINE TAXA FROM MADRID, INCLUDING COMPARATIVE DATA WITH OTHER SPECIES OF THIS SUBFAMILY (LEPIDOPTERA: GEOMETRIDAE: STERRHINAE)
}

\author{
Gareth Edward King* \& José Luis Viejo Montesinos \\ Departamento de Biología (Zoología), Universidad Autónoma de Madrid, C/. Darwin, 2, 28049 Cantoblanco (Madrid) \\ *Corresponding author: sterrhinae@gmail.com
}

\begin{abstract}
Original data are presented which describe ova of the following six taxa in the Sterrhinae Meyrick, 1892: Idaea litigiosaria (Boisduval, 1840), Idaea sericeata calvaria Wehrli, 1927, Idaea ochrata albida (Zerny, 1936), Idaea incisaria (Staudinger, 1892), Idaea cervantaria (Millière, 1869) and Scopula (Glossotrophia) asellaria dentatolineata Wehrli, 1926. Subsequent analysis of SEM imaging provides data related to the chorion structure, as well as that associated with the strategies adopted by females at oviposition under laboratory conditions; comparative data are provided of other European sterrhines.
\end{abstract}

Key words: Lepidoptera; Geometridae; Sterrhinae; ova; morphology; biology; egg positioning.

\section{RESUMEN}

Descripción de los huevos y de las estrategias de puesta de seis taxones de Sterrhinae de Madrid, con datos comparativos de otras especies de la subfamilia (Lepidoptera: Geometridae: Sterrhinae)

Se presentan datos inéditos que describen los huevos de los siguientes taxones de Sterrhinae Meyrick, 1892: Idaea litigiosaria (Boisduval, 1840), Idaea sericeata calvaria Wehrli, 1927, Idaea ochrata albida (Zerny, 1936), Idaea incisaria (Staudinger, 1892), Idaea cervantaria (Millière, 1869) and Scopula (Glossotrophia) aseIlaria dentatolineata Wehrli, 1926. Se ofrece un análisis pormenorizado de las imágenes MEB en cuanto a la estructura del corión se refiere, además de una descripción de las estrategias de la puesta adoptadas por parte de las hembras en condiciones de laboratorio. Se ofrecen datos comparativos con otras especies europeas de Sterrhinae.

Palabras clave: Lepidoptera; Geometridae; Sterrhinae; huevos; morfología; biología; ubicación.

\section{Recibido/Received: 5/08/2015; Aceptado/Accepted: 22/01/2016; Publicado en línea/Published online: 4/03/2016}

Cómo citar este artículo/Citation: King G. E. \& Viejo Montesinos, J. L., 2016. Description of the ova and ovipositional strategies of six sterrhine taxa from Madrid, including comparative data with other species of this subfamily (Lepidoptera: Geometridae: Sterrhinae). Grael/sia, 72(1): e041. http://dx.doi.org/10.3989/graellsia.2016.v72.146

Copyright: (c) 2016 SAM y CSIC. Salvo indicación contraria, todos los contenidos de la edición electrónica de Graellsia se distribuyen bajo licencia de uso y distribución Creative Commons Reconocimiento no Comercial 3.0. España (cc-by-nc).

\section{Introduction}

In the Ennominae, the largest of the four major Geometrid subfamilies (45\% of world taxa: Scoble \& Hausmann, 2007), females of several species, for example, Siona lineata (Scopoli, 1763) lay eggs in batches which can be described as short 'chains' on the margins of blades of grass (Ebert et al., 2003), this strategy resembles that of a related species Aspitates ochrearia (Rossi, 1794), also laying eggs batches in quite extensive 'chains' of several individual ova on plant material (King, personal observation), meanwhile, females 
of Compsoptera jourdanaria (Serres, 1826) oviposit in 'ring-like' clusters exposed on the stems of its food-plant (Fig. 1). In the Sterrhinae (11\% of world Geometrid taxa: Scoble \& Hausmann, 2007), females are not known to adopt either of these strategies, eggs either being scattered whilst the female is in flight, for example, Idaea ochrata (Scopoli, 1763) (Rennwald, 1993) or I. macilentaria (Herrich-Schäffer, 1847) (King, personal observation), or laid individually, or in small clusters, for example, I. longaria (Herrich-Schäffer, 1852) (Fig. 2).

Peterson (1962) published descriptions of five Nearctic sterrhines out of 40 geometrids he worked on three amongst the Idaea Treitschke, 1825: I. demissaria (Hübner, 1831), I. tacturata (Walker, 1861) and I. flavescens (Hulst, 1896), in addition to Scopula aemulata (Hulst, 1896) and Leptostales pannaria (Guenée [1858]. According to Peterson (1962), both I. demissaria and I. flavescens lay at random (ova yellow changing to orange), morphologically, these species' ova have 'six prominent ridges' as well as 'conspicuous transverse striae'; on the other hand, the (vivid red) ova of I. tacturata are laid vertically adhered to the substrate (axis not parallel to substrate) whose surface 'is covered uniformly with small hexagonal pits'. In this latter species, Peterson (1962) emphasised its unique characters quite unlike others in the Idaea, indeed amongst the geometrids as a whole. The reddish-green eggs of $S$. aemulata are laid individually vertically their surface having 'distinct longitudinal ridges with faint transverse striae'. L. pannaria lays greenish-yellow ova, these being relatively 'elongated' with a roughened surface and indistinct longitudinal rows. Peterson (1968) includes data of two additional species: S. enucleata (Guenée, 1857) whose egg is yellowish-white and having a surface "with indented longitudinal ridges extend (ing) lengthwise from pole to pole with about 20 distinct cross striae between them' deposited randomly, and $S$. inductata (Guenée, 1858) whose somewhat adhesive ova are "light cream to near white (with) sixteen faint slightly indented ridges extend (ing) from the obtuse end to the smaller rounded end with very few or no cross striae between them'.

Salkeld (1983) described the ova of nine sterrhine species: two species in Idaea: I. demissaria (Hübner, 1831) and I. dimidiata (Hufnagel, 1767), and four species in the genus Scopula Schrank,

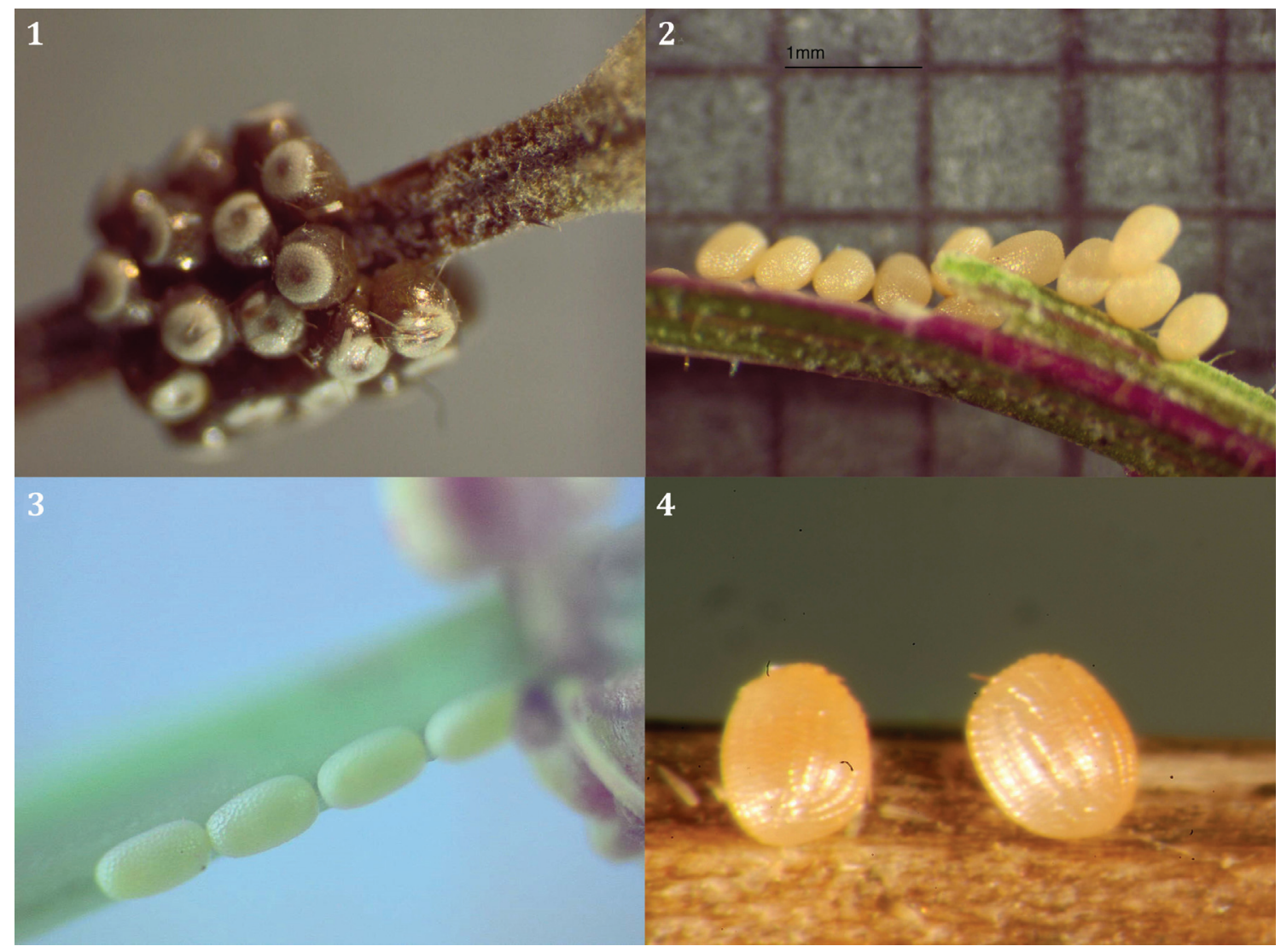

Figs. 1-4.- Egg batch of 1) Compsoptera jourdanaria, El Goloso, Madrid; 2) Idaea longaria, $q$ 2.X.12, Cantoblanco, Madrid; 3) Lythria sanguinaria, + V.11, El Goloso, Madrid; 4) Idaea litigiosaria, + 31.V.09, El Goloso, Madrid; photo: José Martín Cano.

Figs. 1-4.- Puestas de 1) Compsoptera jourdanaria, El Goloso, Madrid; 2) Idaea longaria, o 2.X.12, Cantoblanco, Madrid; 3) Lythria sanguinaria, + V.11, El Goloso, Madrid; 4) Idaea litigiosaria, + 31.V.09, El Goloso, Madrid; imagen tomada por José Martín Cano. 
Table 1.- European Sterrhinae: Ovipositional strategies (Wiltshire, 1962; Salkeld, 1983; Rennwald 1993; Sannino \& Espinosa, 1999, 2002; Ebert \& Steiner, 2001; King, personal observations).

Tabla 1.- Estrategias empleadas por los Sterrhinae europeos en la puesta (Wiltshire, 1962; Salkeld, 1983; Rennwald, 1993; Sannino \& Espinosa, 1999, 2002; Ebert \& Steiner, 2001; King, observaciones personales).

\begin{tabular}{|c|c|}
\hline Taxa & Strategy observed \\
\hline Cleta ramosaria (Villers, 1789 ) & $\begin{array}{l}\text { Ova laid either individually or in twos on } \\
\text { fragments of dry plant material. }\end{array}$ \\
\hline Idaea flaveolaria (Hübner, [1809]) & $\begin{array}{l}\text { Ova scattered in box in late afternoon, } \\
\text { presumably laid at random whilst in flight. }\end{array}$ \\
\hline Idaea muricata (Hufnagel, 1767) & $\begin{array}{l}\text { Deposited in short rows or groups (Ebert \& } \\
\text { Steiner, 2001). }\end{array}$ \\
\hline Idaea litigiosaria (Boisduval, 1840) (Fig. 4) & $\begin{array}{l}\text { Ova laid in twos on the substrate (see text) } \\
\text { (Fig. 4). }\end{array}$ \\
\hline Idaea mediaria (Hübner,1819) & $\begin{array}{l}\text { Laid individually on substrate (fragments of } \\
\text { dry plant material). }\end{array}$ \\
\hline Idaea sericeata calvaria Wehrli, 1927 & $\begin{array}{l}\text { Facultative: Laid scattered or laid ova } \\
\text { individually on the leaves and the stem of a } \\
\text { sprig (see text). }\end{array}$ \\
\hline Idaea macilentaria (Herrich-Schäffer, 1847) & $\begin{array}{l}\text { Ova scattered presumably in flight within the } \\
\text { confines of a container. }\end{array}$ \\
\hline Idaea ochrata (Scopoli, 1763) & $\begin{array}{l}\text { Ova scattered by females in flight } \\
\text { (Rennwald, 1993). }\end{array}$ \\
\hline Idaea ochrata albida (Zerny, 1936) & Ova scattered (but see text). \\
\hline Idaea figuraria (Bang-Haas, 1907) & $\begin{array}{l}\text { Small sample }(\mathrm{n}=5) \text { but suggests ova } \\
\text { laid individually. One ovum deposited on } \\
\text { 'hirsute' flowers of Trifolium hirtum; one laid } \\
\text { on upper surface of polygonale leaf, also } \\
\text { at base of container ( } 2 \text { females in different } \\
\text { containers). }\end{array}$ \\
\hline Idaea laevigata (Scopuli, 1763) & $\begin{array}{l}\text { Ova laid individually or in groups } 2-6 \text { units } \\
\text { in filaments of Poaceae flower, not laid in } \\
\text { Rumex acetosella flowers. One observation } \\
\text { indicates row laid ( } 9 \text { units). Not laid with axis } \\
\text { horizontal to substrate. }\end{array}$ \\
\hline
\end{tabular}

Idaea incisaria (Staudinger, 1892)

Idaea calunetaria (Staudinger, 1859)

Idaea bigladiata Herbulot, 1975

Idaea longaria (Herrich-Schäffer, 1852) (Fig. 2)

Idaea seriata canteneraria Boisduval, 1840

Idaea mancipiata (Staudinger, 1871)

Idaea dimidiata (Hufnagel, 1767)
Ova laid individually or in twos or threes or up to 12 units on substrate varying from silk threads to fragments of dry plant material). Occasionally eggs individually laid on walls of container.

Ova laid in untidy groups, for example on flowers of Trifolium.

Facultative: Ova laid randomly scattered in presence of flowers of Lavendula and Thymus leaves; or laid on walls of container and not on plant material provided (Thymus, Rumex acetosella).

Ova laid on substrate individually or in small untidy groups (Fig. 2), on occasion the eggs are laid in a more regular fashion, for example, following a leaf margin.

In clumps or in rows of several ova (Sannino \& Espinosa, 2002).

Ova laid in small groups or in twos adhered to the substrate; axis horizontal to substrate, Rumex acetosella, for example.

Ova laid 'along edges of substrate, singly and in groups' (Salkeld, 1983).

'Heaps' of ova laid ( $>10)$ on lignified strands of Polygonum aviculare which had come away on being cut.
Material

Bibliography

2 우 15.IV.07, Tres Cantos G.E. King leg.

q 13.VII.14, Tetti Gaina, fraz. Valdieri, 1057 m, Cuneo, Italy, G.E.King leg.

Ebert \& Steiner (2001).

\section{q 31.V.09, El Goloso, G.E.King leg.}

† 21.VI.08, Ciempozuelos, G.E.King leg.

q 19.VI.01, Los Santos de la Humosa; 우 16.V.03, 5.VI.10, Ciempozuelos, G.E.King leg.

Various $q 9$ ex larvae, Alpedrete, 987 m, Madrid, G.E.King leg.

Rennwald (1993).

See text.

2 우 12.VI.13, Cantoblanco, G.E.King leg. et det. (gen. prep. 3879, 3880).

† 5.VI.10, Ciempozuelos;

o 19.VI.12, Madrid, G.E.King leg. et det.

q 20.V.06, Ciempozuelos; +9

23.VI.08, Madrid; $\circ$ 10.V.14, El Regajal, Aranjuez; + 17.V.14, El Goloso, G.E.King leg. et det.

† 15.IX.12, Cantoblanco, G.E.King leg. et det. (3840)

q 18.V.06, Canillejas, (GK290MA); + 29.V.10, Ciempozuelos, G.E.King leg. et det. (3693).

\section{+ 25.IX.07 (GK537MA); \\ 9.X.09; ㅇ 2.X.12, Cantoblanco (3842); \\ o 21.VI.08, Ciempozuelos (GK1142MA)}

G.E.King leg. et det.

Sannino \& Espinosa (2002).

ㅇ 5.VI. 09 (3516); ㅇ 21.VI.11; ㅇ 26.VI.12; ㅇ 18.VIII.12, Cantoblanco, G.E.King leg. et det.

† 26.VII.13 Salkeld (1983). Woodley,

Berkshire, 80 m, UK, G.E.King leg. et det. 
Table 1.- (Continued)

\begin{tabular}{|c|c|c|}
\hline Taxa & Strategy observed & Bibliography \\
\hline Idaea cervantaria (Millière, 1869) & $\begin{array}{l}\text { Ova are laid in a neat row, for example, } \\
\text { on the outer margin of a leaf (see text). } \\
\text { Further observations include 'small groups' } \\
\text { on Thymus lacaitae; rows of various units } \\
\text { on seed pod of Lepidium subulatum and } \\
\text { Reseda stricta. }\end{array}$ & $\begin{array}{l}\text { o 13.VI.04; }+13 . \mathrm{V} .06 ; \text { + } 26 . \mathrm{IV} .08 ; \text { + } 15 . \mathrm{V} .08 \text {, } \\
\text { Ciempozuelos, G.E.King leg. et det. }\end{array}$ \\
\hline Idaea contiguaria (Hübner, 1799) & $\begin{array}{l}\text { Ova in groups tied up in silken strands } \\
\text { suspended from vegetation (Ebert \& Steiner, } \\
2001 \text { ). }\end{array}$ & Ebert \& Steiner (2001). \\
\hline Idaea aversata (Linnaeus, 1758) & $\begin{array}{l}\text { Heaps of ova laid on Poaceae stem; some } \\
\text { oviposited in twos. }\end{array}$ & $\begin{array}{l}\text { Q 21.VII.13, Earley, Berkshire, } 80 \text { m, UK, } \\
\text { G.E.King leg. et det. }\end{array}$ \\
\hline Scopula andalusiaria Wagner, 1935 & $\begin{array}{l}\text { Ova laid individually in confines of container, } \\
\text { mainly on the sides, with a few deposited on } \\
\text { Salsola vermiculata. }\end{array}$ & $\begin{array}{l}\text { + } 21 . \text { VI.08, Ciempozuelos, G.E.King leg. } \\
\text { et det. }\end{array}$ \\
\hline Scopula ornata (Scopuli, 1763) & $\begin{array}{l}\text { Ova deposited individually on underside of } \\
\text { leaf (Ebert \& Steiner, 2001). }\end{array}$ & Ebert \& Steiner (2001). \\
\hline Scopula turbulentaria (Staudinger, 1870) & $\begin{array}{l}\text { Deposited in small groups }(<4) \text { (Sannino \& } \\
\text { Espinosa, 1999). }\end{array}$ & Sannino \& Espinosa (1999). \\
\hline Scopula marginepunctata (Goeze, 1781) & $\begin{array}{l}\text { Ova deposited individually on underside of } \\
\text { leaf (Ebert \& Steiner, 2001). }\end{array}$ & Ebert \& Steiner (2001). \\
\hline Scopula imitaria (Hübner, 1799) & Ova deposited singly on sides of container. & + 7.VI.14, El Goloso, G.E.King leg. et det. \\
\hline Scopula minorata (Boisduval, 1833) & $\begin{array}{l}\text { Deposited either singly or in small groups on } \\
\text { various substrates (container, plant material, } \\
\text { for example, Rumex crispus). }\end{array}$ & $\begin{array}{l}\text { 7.X.07 (GK506MA); Wiltshire (1962). } \\
\text { + 13.X.07 (GK535MA), Ciempozuelos, } \\
\text { G.E.King leg. et det. }\end{array}$ \\
\hline $\begin{array}{l}\text { Scopula (Glossotrophia) rufomixtaria } \\
\text { (Graslin, 1863) }\end{array}$ & $\begin{array}{l}\text { Deposited singly on either plant fragments, or } \\
\text { on the sides of container even if Gypsophila } \\
\text { struthium not included, however, once } \\
\text { available ova are laid on plant. }\end{array}$ & q 31.V.08 Ciempozuelos, G.E.King leg. et det. \\
\hline $\begin{array}{l}\text { Scopula (Glossotrophia) asellaria } \\
\text { dentatolineata Wehrli, } 1926\end{array}$ & $\begin{array}{l}\text { Ova laid in rows of four or five at base of } \\
\text { container (not on sprig) in presence of } \\
\text { food-plant Antirrhinum majus ova or laid in } \\
\text { 'disorganised piles' }(<4) \text { still in presence of } \\
\text { food-plant. }\end{array}$ & $\begin{array}{l}2 \text { 우 22.V.10; }+29 . V .10, \text { Ciempozuelos, } \\
\text { G.E.King leg. et det. }\end{array}$ \\
\hline Timandra comae Schmidt, 1931 & Ova laid individually on Polygonum aviculare. & $\begin{array}{l}\text { 15.VIII.10, Sant'Ana di Valdieri fraz. Valdieri, } \\
981 \text { m, Cuneo, Italy, G.E.King leg. et det. }\end{array}$ \\
\hline Rhodometra sacraria (Linnaeus, 1767) & $\begin{array}{l}\text { Ova deposited usually individually, but also } \\
\text { in twos, often associated with Polygonum } \\
\text { aviculare which can include leaves (upper } \\
\text { surface), stem or exposed roots; other } \\
\text { material includes inner surface of container, } \\
\text { silk threads and paper. }\end{array}$ & $\begin{array}{l}+12 . I X .10 \text {, El Goloso; Skule (1980). } \\
+ \text { 24.X.12, Madrid, G.E.King leg. et det. }\end{array}$ \\
\hline Casilda consecraria (Staudinger, 1871) & $\begin{array}{l}\text { Normally laid singly, sometimes in small } \\
\text { groups, either on leaves or flowers of } \\
\text { Limonium dichotomum or on other } \\
\text { substrates, for example, sides of container. }\end{array}$ & $\begin{array}{l}\text { q 26.IV.08; } 2 \text { q } q \text { 13.VI.10, Ciempozuelos, } \\
\text { G.E.King leg. et det. }\end{array}$ \\
\hline Lythria sanguinaria (Duponchel, 1848) & $\begin{array}{l}\text { Ova deposited in short rows }(>4) \text { on dry } \\
\text { vegetation, such as that of Rumex acetosella } \\
\text { (Polygonaceae), or singly at base of } \\
\text { container. }\end{array}$ & $\begin{array}{l}2 \text { 우 21.IV.13, o 15.IV.14; }+15 . \mathrm{V} .14 \text {, Tres } \\
\text { Cantos, G.E.King leg. et det. }\end{array}$ \\
\hline
\end{tabular}

1802: S. limboundata (Haworth, 1809), S. junctaria (Walker, 1861), S. quadrilineata (Packard, 1876) and $S$. inductata (Guenée, 1858), as well as a species of Cyclophora Hübner, 1822: C. pendulinaria (Guenée, 1858). Salkeld (1983) does not establish any synapomorphy with reference to the ova of the sterrhines. However, amongst the Cosymbini Prout, 1911 and the Timandrini Stephens, 1850, these could include circular-shaped polygonal cells ('areolae' according to Downey \& Allyn, 1984) without there being a regular pattern as such; in the rosette at the anterior pole one finds a uni-cellular polygonal row which surrounds the pole. In amongst the Scopula analysed, the positioning of the polygonal cells follows 
a 'columnar pattern'; in addition in the chorion itself, the cell margins are 'steep' rather than 'gentle'.

Young (2006) gave a full description of the ovum of S. perlata (Walker, 1861) from southern Australia; pointing out the egg as being 'marked on all surfaces by flat, quadrate cells arranged longitudinally on wider lateral sides, with length-wise walls relatively broad, elevated, forming prominent length-wise ribs; transverse walls non-elevated, barely discernible; cells on anterior pole irregular polygons, concave with moderately broad walls overlain with a very narrow shallow reticulum. Aeropyles very inconspicuous, slightly elevated, openings very small, distributed on anterior pole only. Chorion smooth, overlaid with a mesh-like reticulum'.

The bibliography which deals with the European, and by extension, Mediterranean, Sterrhine ova or egg deposition is not extensive, with data in Salkeld (1983), Ebert \& Steiner (2001), Sannino \& Espinosa $(1999,2002)$, in addition to King (2014) (Lythria sanguinaria (Duponchel, 1848) (Fig. 3) (see Table 1). Hausmann et al. (2007) include a SEM image of the ovum of the Macaronesian species: I. nigra Hausmann \& Bläsius, 2007.

This present paper aims to provide original morphological data of the ova of the relatively poorlyknown Mediterranean sterrhine fauna of a limited number of taxa, in addition to data of the ovipositional strategies adopted under laboratory conditions; comparative data are also given for other European species.

The sterrhines are an interesting moth sub-family, especially in the Mediterranean region where they are well-represented faunistically (Hausmann, 2004). This is due to their adaptation to the prolonged summer drought, with most species spending an inordinate length of time in the larval stages, as well as to their ability to deal with dessicated or otherwise sub-standard vegetation. Additionally, the majority of species adopt phenological strategies to cope with the harsh climate (Covell, 1983; Hausmann, 2004), for example, species which are monovoltine tend to emerge in early May allowing the larvae to feed up slowly over the summer as low plant foliage senesces, taking advantage of new plant growth available once rains arrive in the late autumn. This is the case with Idaea ochrata albida (Zerny, 1936), additionally, females of this taxon scatter their ova whilst in flight, leaving the neonates to find food sources at ground level (Rennwald, 1993; Hausmann, 2004).

\section{Material and methods}

Female moths were generally taken at rest during the day in a variety of anthropogenically altered locations in Madrid (or Zaragoza) (Table 2) (railway stations, for example) (I. incisaria, I. longaria, I. cervantaria), or captured, having been disturbed during the day, or at dusk, with a standard butterfly net (I. litigiosaria). Only one taxon is diurnal (I. sericeata calvaria) (Hausmann, 2004). One taxon: $S$. (G.) asellaria dentatolineata was taken at rest on gypsum outcrops.

Female sterrhine moths are not demanding in terms of conditions to be adopted in the laboratory when referring to oviposition requirements (Friedrich, 1986); nevertheless, contact with plant material (stems, flowers, roots) does facilitate the event (Ebert \& Steiner, 2001; Hausmann, 2004). Regarding $I$. incisaria (Staudinger, 1892), I. longaria and I. cervantaria (Millière, 1869), these taxa laying ova individually or in rows or small heaps, or even on the

Table 2.- Localities in Madrid (and Zaragoza) which provided females (and ova as a result).

Tabla 2.- Localidades en Madrid (además de Zaragoza) en las cuales se capturaron las hembras con los huevos obtenidos como resultado.

\begin{tabular}{|c|c|c|c|}
\hline Locality & Altitude & UTM & Characteristics \\
\hline Canillejas (Madrid municipality) & $600 \mathrm{~m}$ & 30TVK47 & $\begin{array}{l}\text { Tagus valley: Urban area city 'park' on gypsym soils with successional } \\
\text { vegetation. }\end{array}$ \\
\hline Cantoblanco (Madrid municipality) & $720 \mathrm{~m}$ & 30TVK48 & $\begin{array}{l}\text { Refers to the railway station, which tends to attract moths to its lights in from } \\
\text { anthropogenically-degraded Quercus ilex light woodland in the immediate } \\
\text { vicinity. }\end{array}$ \\
\hline Cerros de Vallecas (Madrid municipality) & $600 \mathrm{~m}$ & $30 T V K 46$ & Tagus valley: anthropogenically-degraded area of gypsym soils. \\
\hline Ciempozuelos (Madrid) & $600 \mathrm{~m}$ & 30TVK44 & $\begin{array}{l}\text { Tagus valley: anthropogenically-degraded area of gypsym soils; some } \\
\text { Quercus coccifera. }\end{array}$ \\
\hline El Goloso (Madrid municipality) & $720 \mathrm{~m}$ & 30TVK48 & Anthropogenically-degraded Quercus ilex light woodland. \\
\hline El Regajal (Aranjuez municipality) & $600 \mathrm{~m}$ & 30TVK42 & Tagus valley: Quercus ilex-Q. coccifera light woodland; gypsym soils. \\
\hline Los Santos de la Humosa (Madrid) & $600 \mathrm{~m}$ & 30TVK57 & Tagus valley: anthropogenically-degraded area of gypsym soils. \\
\hline Tres Cantos (Madrid) & $720 \mathrm{~m}$ & 30TVK48 & Anthropogenically-degraded Quercus ilex light woodland. \\
\hline Valdespartera (Zaragoza municipality) & $215 \mathrm{~m}$ & ЗоTXM70 & Urban area, successional vegetation on gypsym soils (Ebro valley). \\
\hline
\end{tabular}


walls of a plastic container (King, 2013). I. ochrata is different in that the female drops the ova whilst in flight so that they scatter, which reflects what they do in the wild (Rennwald, 1993). Females of Scopula (Glossotrophia) rufomixtaria (Graslin, 1863) and Scopula (Glossotrophia) asellaria dentatolineata (Wehrli, 1926) tend to ignore sprigs of the food-plant provided and lay eggs individually or in small groups or even clusters, on the walls of the plastic container, although the presence of the plant could be acting as a stimulant to produce eggs. On the other hand, both Rhodometra sacraria (Linnaeus, 1767) and Casilda consecraria (Staudinger, 1871), do lay individually or in twos or threes on the food-plant provided, especially on the flowers (King, 2013). Ova thus obtained were kept at ambient room temperature with no special requirements until the moment of eclosion (incubation times refer to time taken from moment of oviposition until first neonates were noted, with the rider that not all ova eclose at once, but over several days).

Eggs collected were stored in $70 \%$ ethanol in Eppendorf vials.

Images obtained by SEM involved attaching the eggs (70-100\% ethanol gradient beforehand) on to carbon adhesive discs which were adhered to stubs (those already hatched could be attached directly to the carbon discs without having gone through different alcohol gradients), these were then subject to being bathed in gold using a Quorum Q150TS, the images themselves being taken with a SEM model Amray $1810(10 \mathrm{kV})$. Images were taken either at the Universidad de Concepción (Chile) or at the Universidad Autónoma de Madrid.

\section{Results}

Idaea litigiosaria (Boisduval, 1840):

o 31.V.09, El Goloso (Madrid, $720 \mathrm{~m}$ ). Ova laid in twos on the substrate (dry straw) in horizontal position, that is to say, with the micropyle positioned parallel to substrate $(\mathrm{n}=12)$ (Syme, 1961; Young, 2006) (Fig. 4); incubation period: 6.VI.09 (6 days); 9 17.V.14, El Goloso, ova eclosed 24.V.14; 7 days) $(\mathrm{n}=2)$ (females). Ovum'elongated' globe, poles rounded; chorion surface is relatively smooth formed by 'lopsided square-shaped' cells that finish in relatively pronounced longitudinal ridges (Fig. 5); micropyle (Fig. 6) surrounded by a rosette composed of primary cells (6) in the shape of 'petals', and much more oval secondary cells (11) (Fig. 7) (Syme, 1961; Young, 2006).

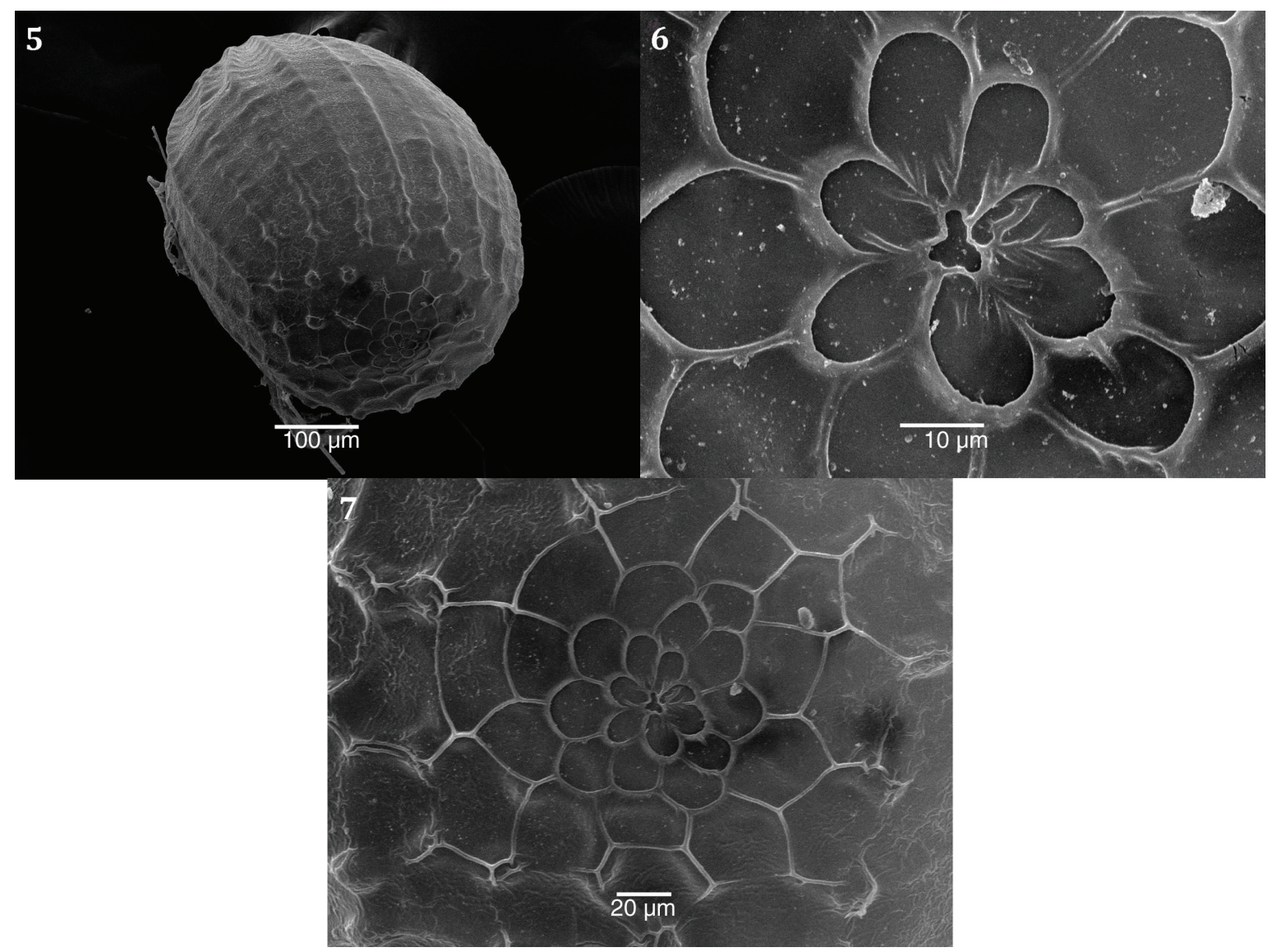

Figs. 5-7.- Idaea litigiosaria ovum, $९$ 31.V.09, El Goloso, Madrid: 5) latero-ventral view; 6-7) rosette, micropyle.

Figs. 5-7.- Huevo de Idaea litigiosaria, o 31.V.09, El Goloso, Madrid: 5) vista latero-ventral; 6-7) roseta, micropilo. 
Idaea sericeata calvaria Wehrli, 1927:

o (larva, 13.IV.08, Tres Cantos, Madrid, $720 \mathrm{~m}$ ); pairing obtained in captivity x $\sigma^{\Uparrow} 31$. V.08, Ciempozuelos, Madrid, $600 \mathrm{~m}$ ). Laid loosely in a plastic container at ambient temperature without special requirements $(n=20)$ 우우 $(n=2)$ : 19.VI.01 (Los Santos de la Humosa, Madrid, $600 \mathrm{~m}$; ㅇ 16.V.03 (Ciempozuelos); incubation period: 6 days. Egg laying strategy in this taxon seems to be facultative (see below): $ᄋ$ (5.VI.10, Ciempozuelos) laid ova individually on the leaves and the stem of a sprig of Medicago sativa (Papilionaceae).

Colour shiny lemon-yellow; egg laid in horizontal position; micropyle positioned parallel to substrate when not laid loosely; roundish in form somewhat flattened ( $\mathrm{n}=2$ ) (Fig. 8), surface with polygonal cells slightly irregular being highly pronounced at their margins suggesting 'fish net'; rosette composed of primary cells (4) and secondary cells (5) which surround the micropyle (Fig. 9) (Syme, 1961; Young, 2006).
Idaea ochrata albida (Zerny, 1936):

O 2.vi.12, El Goloso: ovum oval shape, somewhat flattened, poles rounded, pronounced ridges, cells take shape of 'elongated' rectangles some more regular than others (Fig. 10), the micropyle is almost 'triangular' surrounded by secondary cells in form of 'petals' of different shapes (Fig. 11).

Females oviposit ova at random loosely so that eggs accumulate at base of plastic container (see previous comments) ( $\mathrm{n}=5$ : + 5.VI.99, Valdespartera, Zaragoza, $200 \mathrm{~m}$; $q$ 17.VI.00, Ciempozuelos; O26.V.06, Canillejas, t. m Madrid, $600 \mathrm{~m}$; ㅇ 19.VI.04, Ciempozuelos; + 2.VI.12, El Goloso) however, one occasion witnessed an egg laid on substrate (in horizontal position with micropyle parallel to substrate) (Thymus sprig) although the same female ( 9 19.VI.04) laid rest of eggs loosely. Incubation period according to conditions in captivity is highly variable: $5-13$ days $(\mathrm{n}=6)$. Females obtained 1998-2006: Huesca, Zaragoza, Madrid.

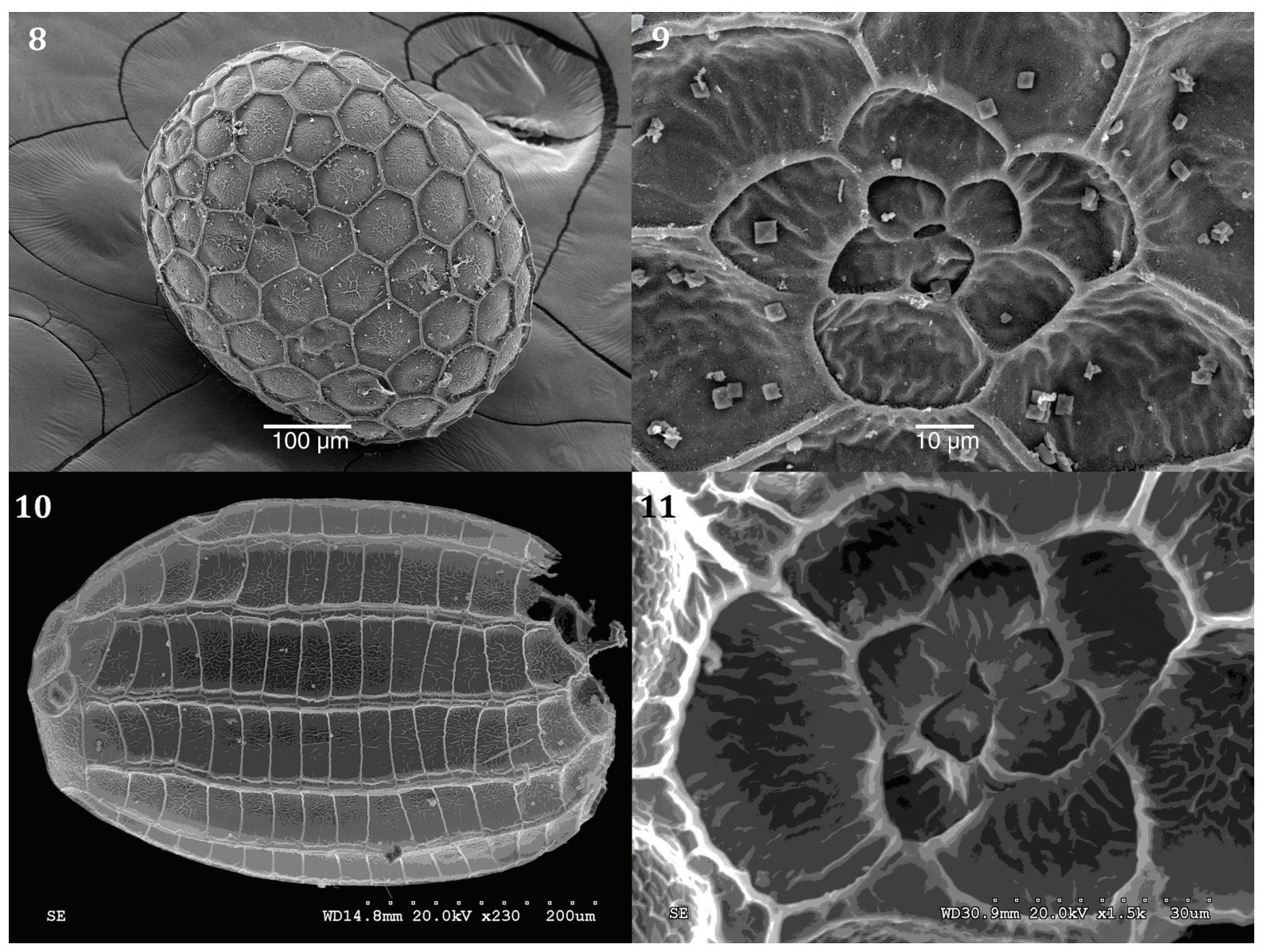

Figs. 8-11.-8) Idaea sericeata calvaria, ㅇ 31.V.08, Ciempozuelos, Madrid, ovum: latero-ventral view; 9) Idaea sericeata calvaria, + 13.IV.08 ex larva, Tres Cantos, Madrid, ovum: rosette, micropyle. 10) Idaea ochrata albida, + 14.VI.08, El Goloso, Madrid, eclosed chorion, lateral view; 11) Idaea ochrata albida, + 2.VI.12, El Goloso, Madrid, ovum: rosette, micropyle.

Figs. 8-11.-8) Idaea sericeata calvaria, o 31.V.08, Ciempozuelos, Madrid, huevo: vista latero-ventral. 9) Idaea sericeata calvaria, + 13.IV.08 ex larva, Tres Cantos, Madrid, huevo: roseta, micropilo. 10) Idaea ochrata albida, 9 14.VI.08, El Goloso, Madrid, corión eclosionado, vista lateral. 11) Idaea ochrata albida, o 2.VI.12, El Goloso, Madrid, huevo: roseta, micropilo. 
Idaea incisaria (Staudinger, 1892):

† 30.v.02, Cantoblanco, Madrid, 720 m. Female oviposits in neat rows on fragments of plant material (horizontal with micropyle parallel to substrate, or more randomly (observations: 9 23.VI.08, Madrid capital (Hortaleza, casco urbano, $725 \mathrm{~m}$ ), slide preparation: GK1143MA, deposited UAM Col. GEK). Egg ovoid form within distinct poles; rosette in proximity to micropyle composed of 'elongated' cells taking shape of 'petal' (Fig. 12); chorion cells take form of irregular rhomboids with very well-defined ridges $(n=1)$ (Fig. 13). Incubation period according to conditions in captivity is rather variable: $4-10$ days $(n=5)$ (females).

Idaea cervantaria (Millière, 1869):

을. 26.IV.08, Ciempozuelos, Madrid. Ova are laid in a neat row, for example, on the outer margin of a leaf of Antirrhinum majus (ㅇ 13.V.06, Ciempozuelos): egg 'gold' in colour; surface relatively 'smooth' (Fig. 14)

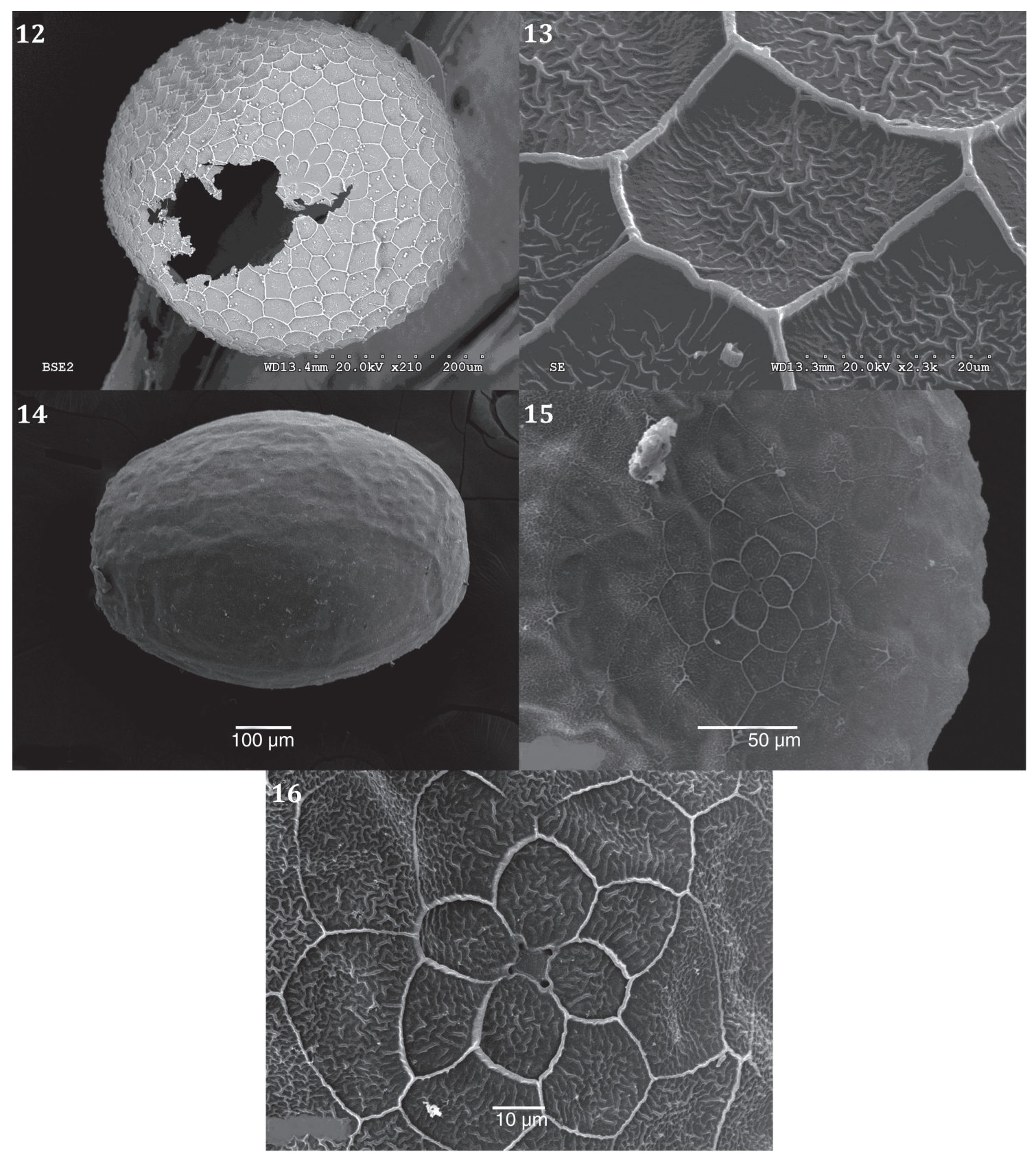

Figs. 12-16.- Idaea incisaria, ㅇ 30.V.02, Cantoblanco, Madrid, 12) eclosed chorion, dorsal view and 13) reticulated chorion walls. 14-16) Idaea cervantaria ovum, + 26.IV.08, Ciempozuelos, Madrid: 14) lateral view; 15) dorsal view, rosette, micropyle; 16) rosette, micropyle.

Figs. 12-16.- Idaea incisaria, ㅇ 30.V.02, Cantoblanco, Madrid, 12) corión eclosionado, vista dorsal y 13) paredes reticuladas del corión. 14-16) Huevo de Idaea cervantariaq 26.IV.08, Ciempozuelos, Madrid; 14) vista lateral; 15) vista dorsal de roseta y micropilo; 16) roseta, micropilo. 
with a distinct patterning of 'blunt' triangle-shaped cells (Fig. 15), poles are 'flattened' (Fig. 14), rosette formed of primary cells in shape of 'petals' (4) and secondary cells (6) $(n=1)$ (Figs. 15, 16); micropyle 'square-shaped'. Incubation period: 6-7 days $(n=4)$ (females).

\section{Scopula (Glossotrophia) asellaria dentatolineata Wehrli, 1926:}

Eggs are laid in rows of four or five at base of container (not on sprig) in presence of food-plant Antirrhinum majus (2 우 22.V.10; Ciempozuelos); $q$ 29.V.10 ova were laid in small piles also with foodplants; on being laid eggs are greenish-white changing to orange with numerous pink spots of varying size on chorion $(\mathrm{n}=10)$; axis horizontal to substrate; somewhat 'flattened' and 'lengthened', anterior pole more rounded (Fig. 17); numerous aeropyles give impression of porous surface, cells 'square-shaped' (Figs. 18, 19); rosette clearly defined, formed by series of five primary cells and secondary cells around micropyle (Fig. 20). Incubation period: 7 days [2 우 22.v.10, Ciempozuelos: larvae eclosed: 29. V.10 $=(n=2)]$.

\section{Discussion and conclusions}

Original data have been provided on the structure of the ova of six sterrhine taxa, in addition, biological data have been given which deal with ovipositional strategies in relation to the substrate. With reference to three taxa: I. litigiosaria, I. sericeata calvaria and I. ochrata albida data were available (Chrétien, 1899a, 1899b; Kristensen, 1966; Rennwald, 1993; Ebert \& Steiner, 2001), although with the latter taxon this data referred to the nominotypical I. ochrata (Scopoli, 1763).

Ovipositional STRATEgIES: The little data that is available on the strategies adopted by European sterrhines is summarised in Table 1 which includes observations of 34 taxa with $21(=61.8 \%)$ in the tribe Sterrhini Meyrick, 1892. Although the data available may be an artifact having been influenced by the conditions under which females were kept in captivity, there are three categories which can be recognised: ova scattered, ova laid individually, or ova laid in groups of varying units. It can be seen (Table 1) that only the Sterrhini are known to 'scatter' their ova

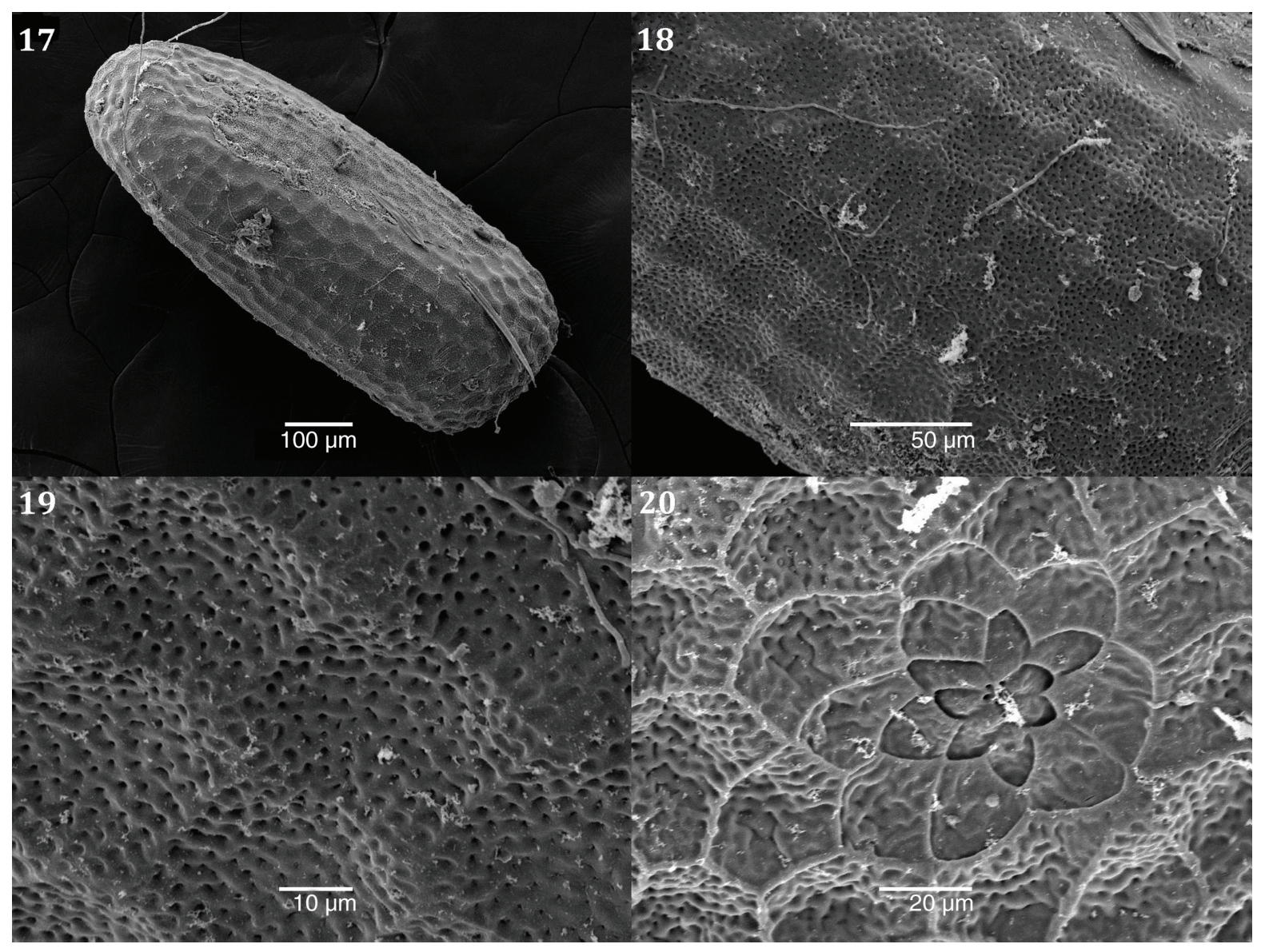

Figs. 17-20.- Scopula asellaria dentatolineata ovum, ㅇ 5.v.05, Ciempozuelos, Madrid: 17) lateral view; 18) cells, lateral view; 19) pitted surface; 20) rosette, micropyle.

Figs. 17-20.- Huevo de Scopula asellaria dentatolineata, + 5.v.05, Ciempozuelos, Madrid: 17) vista lateral; 18) celdas, vista lateral; 19) superficie agujereada; 20) roseta, micropilo. 
including six taxa for which there are data available: I. flaveolaria, I. sericeata calvaria, I. macilentaria, I. ochrata, I. ochrata albida and I. bigladiata, of these six taxa, four taxa seem to be facultative (see Table 1) in terms of whether they 'scatter' their ova or adhere them to a substrate. In addition, all these taxa are diurnal exclusively, or combine nocturnal and diurnal flight patterns (Ebert \& Steiner, 2001; Hausmann, 2004; King, personal observations), with the possible exception of C. ramosaria a diurnal species which adheres ova to a substrate (Table 1). In the Scopulini Duponchel, 1845, it would appear that most species oviposit individually, although only eight European species are detailed in Table 1. Nevertheless, Peterson (1968) mentions two Nearctic species that do oviposit at random (see text above).

Oviposition strategies would reflect how the neonate would be expected to find food, as well as what plant and in what condition it might be expected to be (Zalucki et al., 2002), in this way, if the female scatters its ova (as is the case with the two taxa in this study) larvae would take advantage of geophytes in a generalised way, and by the time eclosion occurs we can also expect senescence to be already advanced in plants that we would expect them to attack. Sterrhines are solitary feeders, so the fact that some taxa do oviposit in groups, albeit in neat rows on dry stalks (as is the case with three taxa in this study), would suggest that it is not so much larval feeding strategies but energy saving by the egg-laying female that is the overriding factor. Those that lay in more limited numbers, I. litigiosaria (two to three), or individually (or in limited groups or clusters) (S. asellaria dentatolineata), presumably do so in order to avoid overcrowding, or in the case of the latter taxon, because it is oligophagous attacking a limited number of scrophulariates (or labiates), Antirrhnum majus, for example; in the wild state, imagines are to be found in the vicinity of this latter plant, so presumably lay on it (King \& Viejo Montesinos, 2010).

Table 3.- The six sterrhine taxa and morphological categories of the eggs according to Salkeld (1983).

Table 3.- Categorías morfológicas de los huevos de seis taxa de Sterrhinae, según Salkeld (1983).

\begin{tabular}{lcc}
\hline Taxa & $\begin{array}{c}\text { 'netted' } \\
\text { chorion }\end{array}$ & $\begin{array}{c}\text { 'ridged' } \\
\text { chorion }\end{array}$ \\
\hline Idaea litigiosaria (Boisduval, 1840) & & $\mathrm{x}$ \\
I. sericeata calvaria Wehrli, 1927 & $\mathrm{x}$ & \\
I. ochrata albida (Zerny, 1936), & & $\mathrm{x}$ \\
I. incisaria (Staudinger, 1892), & $\mathrm{x}$ & \\
I. cervantaria (Millière, 1869) & $\mathrm{x}$ & \\
$\begin{array}{l}\text { Scopula (Glossotrophia) asellaria } \\
\text { dentatolineata Wehrli, 1926 }\end{array}$ & $\mathrm{x}$ \\
\hline
\end{tabular}

Morphology of the ova: According to Salkeld (1983) (Table 3 groups the six taxa analysed in this paper in the same way) the chorion of Idaea ova can be divided into two categories: 'netted' and 'ridged'; the same author also stated that oviposition mode does not correlate with the chorion category. Salkeld (1983) indicated that the eggs of Scopula (of the four species he analysed) follow the same, or very similar, chorion pattern the only taxon in this genus analysed in the present paper, S. asellaria dentatolineata, does not belong to the 'ridged' chorion group, but in a general way, to Salkeld's 'netted' category. The chorion of I. cervantaria also exhibits a less 'pronounced' 'nettedness'. The recently described I. nigra (Hausmann et al., 2007), which included a SEM image of the ovum, might be included in the category of 'ridged' chorion, although it should be stated, that the particular form it shows would require a more detailed analysis, i.e. that it does not follow the pattern established by Salkeld (1983).

\section{Acknowledgements}

Kindest thanks to Dr. José Martín Cano (Universidad Autónoma de Madrid, now retired) who took the photograph of the I. litigiosaria egg. Also to the Facultad de Ciencias Biológicas y Oceanográficas of the Universidad de Concepción (Chile) for the SEM images of the eggs of I. litigiosaria, I. sericeata calvaria, I. cervantaria, and $S$. (Glossotrophia) asellaria dentatolineata on whose premises the first-named author studied under the auspices of Luis Parra (2010-2011). It should be added, that the Sección de Investigación at the Universidad Autónoma de Madrid provided a grant to enable the first-named author to study in Chile in 2010, for which we are most grateful.

\section{References}

Chrétien, P., 1899a. Les premiers états de l'Acidalia litigiosaria B. (Lép.). Bulletin de la Société entomologique de France, 1899: 181-183.

Chrétien, P., 1899b. Les premiers états de l'Acidalia sericeata Hb. (Lép.). Bulletin de la Société entomologique de France, 1899(7): 127-129.

Covell, C. V., 1983. The state of our knowledge of the Neotropical Sterrhinae (Geometridae). Second Symposium on Neotropical Lepidoptera, Arequipa, 1: 1-23.

Downey, J. C. \& Allyn, A. C., 1984. Chorionic sculpturing in eggs of Lycaenidae. Part II. Bulletin of the Allyn Museum, 84: 1-44.

Ebert, G. \& Steiner, A., 2001. Sterrhinae. In: Die Schmetterlinge Baden-Wüttermbergs, Band 8: Nachfalter VI, Geometridae. E. Ulmer. Stuttgart. 541 pp.

Ebert, G., Steiner, A. \& Trusch, R., 2003. Ennominae. In: Die Schmetterlinge Baden-Wüttermbergs, Band 9: Nachfalter VII, Geometridae. E. Ulmer. Stuttgart, 609 pp.

Friedrich, E. 1986. Breeding Butterflies \& Moths. A practical handbook for British and European species. A. Harley Books. Essex. 176 pp.

Hausmann, A., 2004. Sterrhinae. In: Hausmann, A. (ed). The Geometrid Moths of Europe, vol. 2. Apollo Books. Stenstrup. 600 pp. 
Hausmann, A., Miller, M. A., Leipnitz, M. \& Bläsius, R., 2007. Idaea nigra Hausmann \& Bläsius, sp. n. from La Gomera, Canary Islands, Spain (Lepidoptera; Geometridae, Sterrhinae). SHILAP Revista de lepidopterología, 35(140): 499-505.

King, G. E., 2013. Contribución al conocimiento de la biología y morfología de los estados inmaduros de la subfamilia Sterrhinae Meyrick, 1892 (Insecta: Lepidoptera: Geometridae) en el sur de Madrid. PhD Thesis. Departamento de Biología (Facultad de Ciencias), Universidad Autónoma de Madrid. (unpublished).

King, G. E., 2014. Contribution to an understanding of the early stages (ovum, larva) of Lythria sanguinaria (Duponchel, 1842) with reference to two species in the Rhodometrini Agenjo, 1952 (Geometridae: Sterrhinae) (data from central Spain). In: Hausmann, A. (ed.). Proceedings of the 8th Forum Herbulot 2014 (How to accelerate the inventory of biodiversity), Schlettau. Spixiana, 37(2): 263-264.

King, G. E. \& Viejo Montesinos, J. L., 2010. Geometrid and their food-plants in the south of Madrid (Central Spain) (Geometridae). Nota lepidopterologica, 33(1): 45-61.

Kristensen, N. P., 1966. Notes on Sterrha ochrata, a moth new to the Danish fauna (Lepidoptera: Geometridae). Entomologiske Meddelelser, 34: 214-220.

Peterson, A., 1962. Some eggs of moths among the Geometridae-Lepidoptera. The Florida Entomologist, 45(3): 109-119. http://dx.doi.org/10.2307/3492561

Peterson, A., 1968. Eggs of moths from additional species of Geometridae-Lepidoptera. The Florida Entomologist, 51(2): 83-94. http://dx.doi.org/10.2307/3493606

Rennwald, K., 1993. Die Vegetation und Flora der Rheindämme Mittelbadens und ihre Bedeutung für die Kleinspanner (Lepidoptera: Geometridae; Sterrhinae). Diploma Arbeit. Universität Heidelberg. 188 pp. (unpublished undergraduate dessertation).
Sannino, L. \& Espinosa, B., 1999. Aspetti morfologici ed etologici di Scopula turbidaria (Lepidoptera: Geometridae). Fragmenta entomologica (Roma), 31(2): 377-395.

Sannino, L. \& Espinosa, B., 2002. Note sulla morfología degli stadi preimmaginali di Idaea seriata (Lepidoptera: Geometridae). Fragmenta entomologica (Roma), 4(1): 189-206.

Salkeld, E. H., 1983. A catalogue of the eggs of some Canadian Geometridae (Lepidoptera), with comments. Memoirs of the Entomological Society of Canada, 115(S126): 1-271. http://dx.doi.org/10.4039/entm115126fv

Scoble, M. J. \& Hausmann, A., 2007. Online list of valid and available names of the Geometridae of the World. Lepidoptera Barcode of Life, iBOL; available in: http:// www.lepbarcoding.org/geometridae/species_checklists. php Accessed: 19.II.12.

Skule, B., 1980. Rhodometra sacraria L. Lidt om artens biologi og udbredelse, samt om den anden europaeiske Rhodometra-art: Rhodometra anthophilaria $\mathrm{Hb}$. Lepidoptera (København), 3(9): 261-268.

Syme, P. D., 1961. The morphology of lepidopterous eggs, with descriptions of two hundred and fortyeight species. Ph. D. Thesis. University of Toronto. (Unpublished).

Wiltshire, E. P., 1962. Early stages of the Old World Lepidoptera XII. Journal of the Bombay Natural History Society, 59: 778-800.

Young, C. J., 2006. Descriptions of the eggs of some southern Australian Geometridae (Lepidoptera). Zootaxa, 1287: 1-294.

Zalucki, M. P., Clarke, A. R. \& Malcolm, S. B., 2002. Ecology and behaviour of first instar larval Lepidoptera. Annual Review of Entomology, 47: 361-393. 